\title{
UNCOMPROMISING GAZE: THE ART OF ALBERT CHIARANDINI O.S.A., F.I.I.A.L.*
}

\author{
Olga Zorzi Pugliese, Guido Pugliese, Angelo Principe
}

\begin{abstract}
Summary: A close analysis of the paintings by Albert Chiarandini inscribed in several genres (portraiture, landscapes and compositions) and evaluated in light of the artist's life experience, diary reflections, and personal interviews, reveals his fundamental concern for social justice. He chooses to portray the downtrodden with empathy, views important monuments from unusual angles that highlight their unpretentious side, and hints at the menacing conflict inherent in apparently pastoral scenes. His choice of political events and personages (Attila the Hun attacking Aquileia, the FLQ and Women's Liberation movement in Quebec, the sacrifice of the outspoken Savonarola) underscores his condemnation of war and the suppression of personal freedoms. The artist's numerous selfportraits and cameo appearances in other paintings are particularly indicative of the essence of Chiarandini's works: his stance as a freedom fighter and his penetrating gaze into the heart of humankind.
\end{abstract}

\section{Introduction: Chiarandini's}

Professional and Personal Biography and His View of Life

Listed in various dictionaries of North American artists, ${ }^{1}$ Albert Chiarandini (Udine, Italy 1915 - Toronto 2007) had his first exhibit in 1938 at the Art Gallery of Toronto (now Art Gallery of Ontario) with the Ontario Society of Artists (O.S.A.) in the company of some members of

* Some information for this article was gathered from interviews with the artist in 2004 at the artist's home and subsequently at the numerous exhibits that took place at the Georgina Art Centre \& Gallery and also in Toronto. Many valuable materials preserved by the family have been utilized: the artist's scrapbook, photographs, documents, and especially his personal diaries. Heartfelt thanks go to Joan Chiarandini Tadier, to her husband Patrice Tadier, and to Dr. Rudy Chiarandini for their collaboration and generosity. The assistance of the Executive Director and the Curator of the Georgina Gallery and also of the archivists of the National Gallery of Canada in Ottawa and of the Ontario College of Art is gratefully acknowledged.

1 Who Was Who in American Art, 634. Artists in Canada, 158. Mc Mann, Biographical Index of Artist in Canada, 43. 
the Group of Seven. ${ }^{2}$ Elected Fellow of the International Institute of Arts and Letters (F.I I A.L.) in 1960 and appointed member of the O.S.A. in 1968, he was among the artists featured in the 2005 Ontario Celebrations for the Group of Seven ${ }^{3}$ and in the March 2011 exhibit held at the Joseph D. Carrier Art Gallery at the Columbus Centre that included works by the Group of Seven from the McMichael Canadian Art Collection. ${ }^{4}$ More than 180 of Chiarandini's paintings are now on permanent exhibit at the Georgina Art Centre \& Gallery in Sutton West, Ontario, the donation of these works to the gallery having been heralded in many newspaper articles. 5 The rest of his production, totaling approximately 3,000 paintings, practically all in oil, and covering many genres including landscapes and townscapes, large compositions, and especially portraits, is found in other Ontario galleries, in many public institutions as well as in private collections, and has been the subject of brief newspaper and magazine articles in Canada and Italy over the years. ${ }^{6}$

Born in Udine in the region of Friuli in 1915, Umberto, known in Canada as Albert Chiarandini,7 experienced difficult years in his early childhood. While his father fought in World War I, he sought safety in a refugee camp in southern Italy with his mother and brother, suffering severe illness including infections that permanently affected his sight in

2 The catalogue of the Ontario Society of Artists 66th exhibition appears on the association's web site.

3 The Group of Seven Project 19202005 by Dennis Reid et al.contains several references to Chiarandini (102), an entry on him by Jaclyn Glionna (106), and reproductions of two of his landscapes (107, and colour plate 17).

${ }^{4}$ Articles on the event, one unsigned and another by Caterina Rotunno, appeared in Tandem/Corriere canadese.

5 An unsigned article, "Chiarandini Discovered," 4, speaks of the Chiarandini works donated to the gallery by Bruce Smith (1925-2005), one of the artist's students and an artist himself. It stresses the "bold brush strokes, vibrant colours [ ...] intrinsic love of nature," and the "power of the stroke style" evident in Chiarandini's oil paintings.

6 Some of the Canadian newspaper articles are cited below. An article also appeared in Il gazzettino di Udine and Il Friuli. Cultura. Settimanale, both authored by Vidoni.

7 A shorter essay by Olga Zorzi Pugliese on his personal background and an overview of his contribution to the genre of portraiture in particular appeared recently in a volume edited by Anna Pia De Luca. Basic information on Chiarandini and images of many of his works are found on the following websites: www.albertchiarandini.com and www.studio737.com/AlbertChiarandini. 
one eye. ${ }^{8}$ Back home in Chiavris, then on the outskirts of Udine, he aspired to be an artist, but had to make his own paintbrushes from bristles cut from the brushes used to whitewash the exterior walls of the shed behind the house (or from his father's shaving brush, as legend has it), using the side wall of the shed for a canvas. ${ }^{9} \mathrm{He}$ attended school and studied art in Udine, completing the third year of the Scuola Secondaria di Avviamento Professionale (High School for Professional Development), after which he apprenticed with the sculptor Luigi Moro (1881-1946). In 1932, at the age of seventeen, he left fascist Italy with his mother and brother and joined his father in Canada. In Toronto he attended the Ontario College of Art (now Ontario College of Art and Design University), ${ }^{10}$ where he studied with various important Canadian artists. ${ }^{11}$ Feeling morally compelled to work and contribute financially to his family, he transferred from day to night classes. ${ }^{12}$ Even as a part-time student, however, he was awarded scholarships and successfully completed the program with honours. ${ }^{13}$ In the early years in Canada, Chiarandini was often torn between the need to earn a living for his family, on the one hand, and, on the other, the desire to be free to paint and express himself artistically. In order to support his wife and two children, he had to work-at least until 1960-even in the field of construction. ${ }^{14}$ In an entry from 1959 in one of the numerous diaries that he kept, he expressed regret that he could not devote himself fulltime to his art, finding the world of business so alien

8 This war experience is narrated dramatically in his mother's memoirs.

9 The house and shed still stand at 12 via Monte Vodice.

10 He received scholarships (see The Ontario College of Art Prospectus) and successfully completed the program with honours.

11 On the Information Form that he submitted to The National Gallery of Canada in 1965, he listed his teachers in the following order: [the muralist] Frederick S. Challener (1869-1959), [portrait and landscape painter] John Martin Alfsen (1902-72), and [landscape artist] J.W. Beatty (1869-1941).

12 Finding it unacceptable that his father and brother should return home from work in dirty clothes and carrying lunchboxes, while he attended college in his finery, he gave up his full-time studies.

13 The information is included in The Ontario College of Art Prospectus for Session 1934-1935, 28 and also the Prospectus 1936-1937, 29. The artist had proudly framed his OCA certificate of completion with honours.

14 In 1941, according to his own account on The National Gallery of Canada form, he was invited by the Italian government to study in Italy, but war prevented it. 
to his natural inclinations. He observed that "The world is cruel." 15 Yet, because of his extraordinary talent, his reputation as an artist continued to grow. By the late 1950s Chiarandini was well known and, as a master of portrait painting in particular, he came to be much sought after. He was hired at the Ontario College of Art as an instructor in portraiture for a few years. ${ }^{16}$ In addition to teaching courses at Northern Secondary School in Toronto for thirty years from 1963 to 1993 , he continued into his late eighties to teach privately. At his death in 2007 he left a strong legacy among his students, many of whom have written strong and moving testimonials of his dedication and frank approach.

A journalist who commented on a group of his portraits- the hippy portraits discussed below_observed that Chiarandini had a natural insight into the mind of his subjects and empathy for their feelings "although he ... never studied psychiatry." 17 Given his talent, Chiarandini received numerous commissions to paint university and hospital administrators and prominent citizens, including the Reverend Matheson, Principal of Emmanuel College, in 1966, Dr. Maxwell K. Bochner, who revolutionized laser eye surgery, in 1970, and the elegant Anne Lazare Mirvish, patron of the arts, in 1962. ${ }^{18}$ But there were other genres of painting and other types of portraits that inspired him. These more spontaneous works were to be vehicles for expressing his views on humanity and its weaknesses and his strong compassion for the victims of oppression, injustice and inequality. Chiarandini held pessimistic views about life and society. His diary entries in the 1960s refer to humankind's materialism and dishonesty (29 March 1967), to our "monstruous society" (11 April 1968) and "ugly humanity" (26 January 1969). In the mid-1980s too he denounced this "crazy world" (3 January 1984) and the North American preoccupation with money. 19

15 Diary entry for 23 March 1959 . The ambivalence of his situation is reflected in the fact that he even sketched on the back of bank slips.

${ }^{16}$ For a three-or four-year period in the late 1960s he taught evening courses in portraiture at the Ontario College of Art. His appointment was announced in The Ontario College of Art Quarterly.

17 Katz, "Derelicts Need Love, Artist Says," 62. He displayed psychological keenness in his other daytime activities in the 1950s, as is noted by businessman and philanthropist Murray Dryden, who in his book With God Nothing is Impossible, 84, calls Chiarandini "a cunning psychologist."

18 The Matheson portrait is analyzed and reproduced in the Olga Zorzi Pugliese article; the Bochner portrait is located in the doctor's lounge at Scarborough Hospital, the Anne Mirvish portrait is in the Chiarandini/Tadier collection.

19 Letter written in Italian from Italy to his mother on 7 August 1985. 
"Life is not easy" was the refrain that he repeated during interviews and conversations in 2004. This worldview, which he verbalized in his diaries, also emerges in visual form from his paintings.

An outspoken man, Chiarandini was critical of developments in the modern art world. He was never an abstract painter ${ }^{20}$ : indeed he prided himself on being a more traditional figurative artist, suffering perhaps some consequences for going against the current. Yet the style he adopted is certainly not photographic realism. Formed on the classics but influenced by Canadian movements, he developed a sort of symbolic realism, which is clearly exemplified in his Homage to Paganini. A portrait based on the nineteenth-century depiction by Jean Auguste Dominique Ingres (1780-1867), Chiarandini's work from 1962 is more than a tribute to the musician, to the French painter and to the art of portraiture. Wavy sound lines, a plurality of colours reminiscent of an artist's palette, feminine faces, and other details in the background suggesting inspiration point to the fact that the painting is a veritable hymn to creativity itself. ${ }^{21}$

\section{Portraits}

The subjects that Chiarandini himself chose to immortalize in paint differed sharply from the eminent individuals of his commissioned works. They include his family members, of course, and most originally perhaps a great number of modest figures, often those marginalized by society, whom he appears to have championed. Most remarkable in this category are the socalled "derelicts," 22 as one journalist called them, more precisely the hippies from the 1960s, nonconformist and antiestablishment young persons, among whom some American draftdodgers, who frequented the Yorkville area of Toronto. ${ }^{23}$ According to Chiarandini's own account, preferring to

20 On the Information Form referred to above, under the section pertaining to "Particulars of any honours conferred in connection with art", Chiarandini wrote with some bitterness the following comment: "Being a portrait and figure painter, I don't get much credit ... these days!! I regret that God did not give me the gift to paint A-B-S-T-R-ACT."

${ }^{21}$ For a detailed analysis and reproduction of this work and also of the Yorkville Hippy with a Cane see O.Z. Pugliese.

22 Katz, 62.

23 A very good commentary on these and other portraits, written by Christie Jones of the Georgina Art Centre, is included in the brochure for the Portraits exhibit held in August-September 2007. Interestingly, a recent painting of a young streetperson by contemporary Canadian artist Steven Shearer was among the works selected to represent Canada at the Venice Biennale in 2011, accord- 
have real people and not professional models pose for him, he would go to Yorkville and invite the hippies to sit for him, paying them an hourly rate, at times deferring payment to ensure they would return and enable him to complete the paintings. The project actually began as an exercise with his students in order to teach them how to achieve the expression of human suffering. Chiarandini's depiction of the hippies is particularly fascinating because of his attractive and sympathetic rendering of them. These large portraits, numbering approximately a dozen in total, are mentioned in his diary entries of 1967 and May 1969, and are now in important art galleries. They present handsome young men (and one woman) with long hair, in whose eyes the artist said he saw a certain sense of hopelessness and need for affection. What is striking is the almost effeminate quality, sensitivity, and gentleness that he finds in these idealistic dreamers and antiwar pacifists, especially if we keep in mind that their physical appearance and presence was not appreciated by the co-tenants in the Yonge St. building where the artist's studio was located. ${ }^{24}$ The portraits Chiarandini painted of them are in a variety

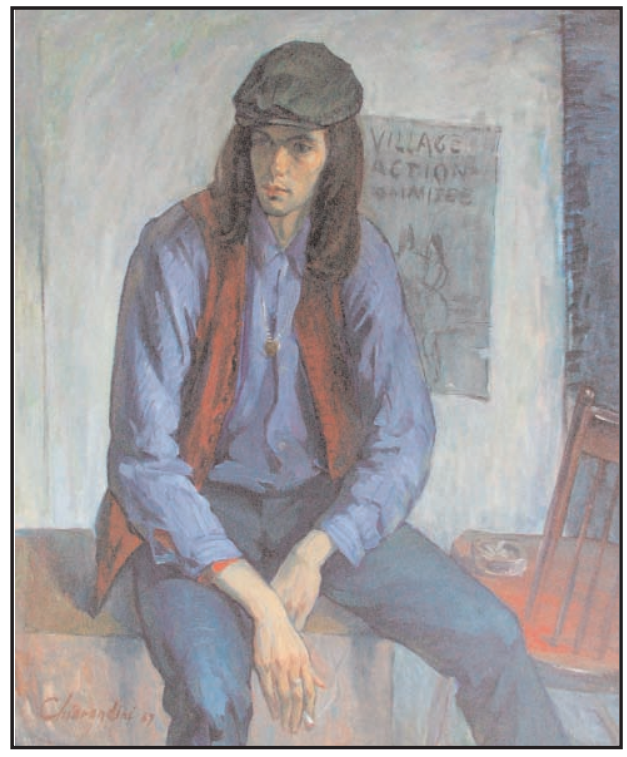
of dominant colours and include particular backgrounds. ${ }^{25} \mathrm{~A}$ sign behind the blue figure from 1967 (fig. 1) (located in the

Figure 1.

Portrait of the Yorkville Hippy

David, 1967.

Oil on board, $142.2 \mathrm{~cm} . \mathrm{x} 106.7$

$\mathrm{cm}$. Toronto, The Joseph D.

Carrier Art Gallery, Columbus

Centre (Photo courtesy of the

Estate of Albert Chiarandini)

ing to reports in the The Globe and Mail (3 August 2010) and Toronto Star (3 August 2010 and 31 May 2011).

24 One of the works appears as an illustration in Richmond, 45. The treatment of the hippies at the hands of Canadian authorities is analyzed thoroughly in an essay by York University historian Marcel Martel: “"They Smell Bad, Have Diseases and are Lazy': RCMP Officers' Reporting on Hippies in the Late Sixties."

25 The Yorkville Hippy with a Cane portrait at the Georgina Art Gallery is analyzed and reproduced in O.Z. Pugliese. 
Carrier Gallery in Columbus Centre) — a portrait of a young man who is now an award-winning playwright in Montreal-reads "Village Action Committee" and on the flyer there is a sketch of a couple embracing. A manifesto declaring "Make love no[t] war" appears in several other portraits in this series, behind the barefoot hippy dressed in blue and red, and also in the portrait of David's girlfriend Elizabeth, the only female represented in the hippy series. This work was sold by the artist to David when, in the early 1970s, the young man had succeeded in selling his first script and returned to inquire about the two portraits. Although his own had already been acquired by a gallery, Chiarandini was moved by the young man's visit and sold Elizabeth's portrait to him for the small sum he had to offer. ${ }^{26}$

Other individuals that Chiarandini painted were chosen from among the men standing in front of the Scott Mission in Toronto, an institution that offers shelter and assistance to the homeless. In his diaries Chiarandini mentions finding a hapless man named Meyer Ellison there in February of 1974 and painting him in his studio on a number of days in the following two months. One of these portraits is now in the National Archives of Canada in Ottawa. Another, titled The Only Friend, Man from the Scott Mission, shows a sign behind the figure indicating the location and a pigeon at his feet eating crumbs fallen from the food he likely had just

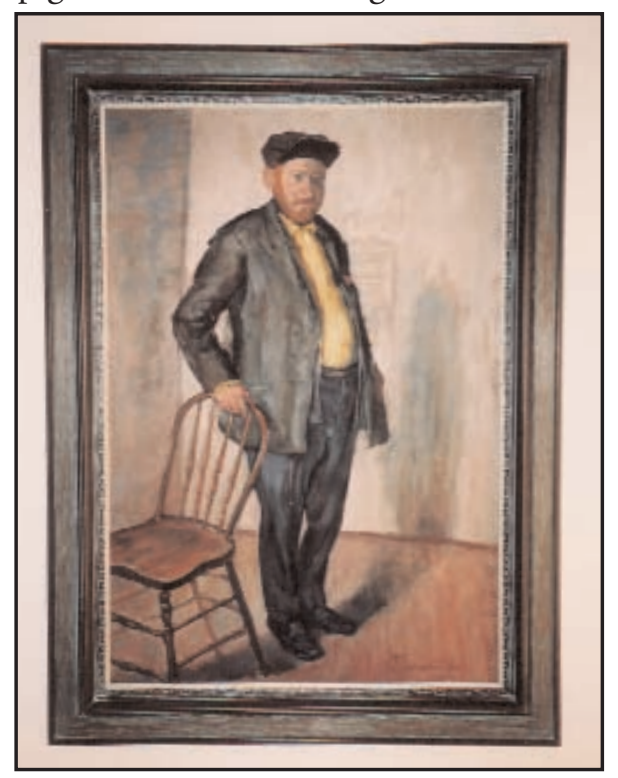
received from the Mission. In another painting Meyer appears standing beside a chair (fig. 2),

Figure 2.

Meyer Ellison and Chair, 1974.

Oil on board, $71.1 \mathrm{~cm} . \times 48.3 \mathrm{~cm}$.

Toronto, Chiarandini/Tadier Collection (Photo courtesy of the Estate of Albert Chiarandini)

26 The anecdote about David Fennario (born Wiper in 1947) is told in e-mail correspondence received from Joan Chiarandini Tadier in August 2005 and confirmed in an e-mail message from David Fennario to Joan Tadier in June 2008. 
the standing position and empty chair implying the lack of a permanent home and its comforts.

One portrait by Chiarandini is of a downtrodden, middle-aged man from Quebec named Wilfred Pouliot. ${ }^{27} \mathrm{He}$ was from a very old family that spread throughout North America and traced its roots back to a single ancestor named Charles Pouliot, a "charpentier" (shipbuilding carpenter ${ }^{28}$ ) who had arrived in Canada from France in the middle of the seventeenth century. ${ }^{29}$ The family genealogy had been detailed in a scholarly publication, and Pouliot proudly lent a copy of it to Chiarandini. Unlike the other Chiarandini subjects who remain officially anonymous, this large portrait from 1965, appropriately titled The French Connection, has the man's name inscribed on the cushion. Pouliot is depicted with a beard and holding a cigarette. Fallen on hard times, he attempts, nonetheless, with the white shirt he wears, for instance, to maintain his dignity. What strikes the viewer is the very uncomfortable position he is in, neither seated nor standing, his eyes filled with anxiety. Torn between his family's prestigious European past and his impoverished condition, Chiarandini's Pouliot may express the essence of being Canadian, especially a hyphenated Canadian, the uneasy feeling, that is, of being caught between two cultures.

In choosing figures for his portraits Chiarandini displayed a predilection for revolutionary figures, and these were from both the contemporary world and ancient history. Early in his career in Toronto, probably around 1950 , he painted a portrait of the Italian-Canadian anarchist from the province of Udine, Attilio Bortolotti (1903-95). Bortolotti was known for his social conscience and strong convictions and for his relations with the famous Russian-American activist Emma Goldman who saved him from deportation in 1939-40. During an interview in 2004 Chiarandini mentioned Bortolotti, referring to him in favourable terms precisely as a "revolutionary." A comment written in the artist's diaries on 5 April 1968 is also noteworthy: the day after Martin Luther King was assassinated he wrote that the black civil rights leader was "a great mart[y]r for the cause of freedom."

One of the historical personages attracting Chiarandini's attention was Savonarola, the Renaissance preacher who challenged the Church and was executed in 1498. Chiarandini's portrait of Savonarola dated 1962 (fig. 3)

27 This is reproduced in the article by Pugliese.

28 Franco Pierno of the University of Toronto has clarified the meaning of the Old French term.

29 Pouliot, Cahier généalogique Pouliot. 


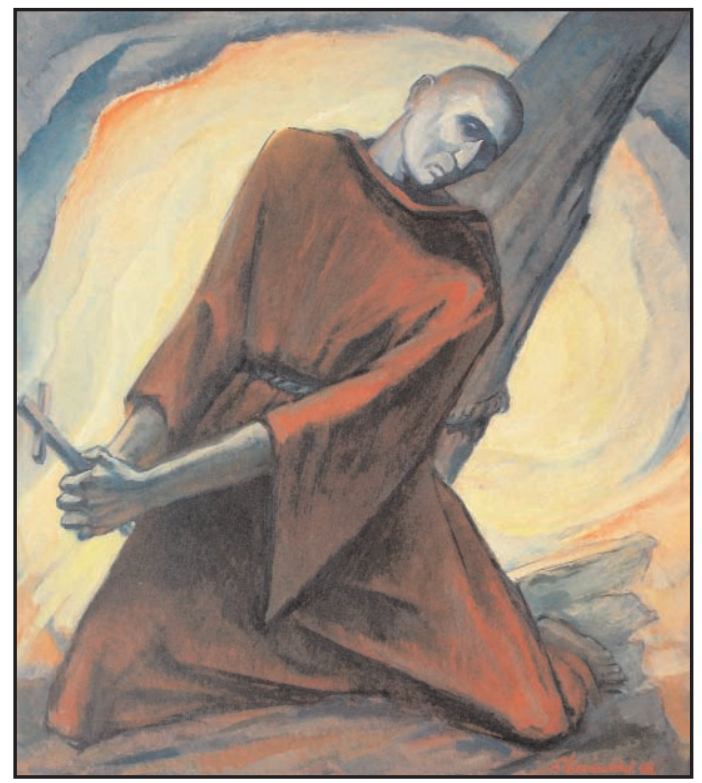

Figure 3.

Savonarola: A Study in

Triangles, 1962.

Oil on board, $86.4 \mathrm{~cm}$. $\mathrm{x}$

$76.2 \mathrm{~cm}$. Toronto,

Chiarandini/Tadier

Collection (Photo courtesy

of the Estate of Albert

Chiarandini)

is not a particularly accurate representation, since the friar is not wearing the standard white and black robe of the Dominicans nor the shorter tunicle he was left in after being stripped of his habit at the time of his execution. Rather, his full-length habit is a reddish brown that might suggest a sacrificial victim, as the pose of the man, tied to a stake, hands tightly grasping a crucifix, indicates (and as the use of this colour in other paintings too suggests). The harsh angularity and tilted position of the composition emphasizes the idea of suffering, and the triangles that cross each other (instead of forming perfect pyramidal forms as in traditional paintings of the Renaissance), here may express anguish. If the trinity is alluded to, criticism of religious institutions is probably implied - something that would be in keeping with the artist's thinking. A second version of the Savonarola portrait, also from 1962, has the friar collapsing to the ground, the crucifix still firmly grasped in his right hand. In this painting the artist experiments with another geometrical form, in this case a slightly elongated circle, a shape that has also traditionally symbolized perfection and divinity. Returning again to this subject years later in 1978, in a work now found at the Georgina Gallery, the artist portrayed Savonarola in a similar manner but this time with the addition of a second figure, namely, a soldier arriving dramatically on horseback with torch in hand ready to set the pyre ablaze as a seemingly willing instrument of the decrees of the powerful. 


\section{Landscapes}

Although specializing as a portrait artist, Chiarandini was fascinated by the natural wonders of his adopted land. He spent long hours at a time painting on location, trying to capture the spirit of nature. While the Group of Seven painters concentrated on the prestigious Georgian Bay and Algonquin areas, Chiarandini chose as his "local colour" 30 the small towns of Ontario and especially the countryside in York Region and Georgina Township to the north of Toronto, much of which is now lost to residential housing development. Quite typically, his numerous landscapes and cityscapes (or rather townscapes), ${ }^{31}$ which he continued to produce right to the last years of his life, display an interest in humble subject matter. There are natural scenes of various types: Lake Wilcox (1982), Autumn Leaves (early 1960s), and a few winter scenes like the predominantly white painting of trees displaying impressionistic techniques similar to those of the Group of Seven. Orange colours often dominate in his painting of sunsets both Canadian and Italian; a barn in Richmond Hill, Ontario (1973) that seems to announce fire and storms, and a hilly area in Soprapaludo near San Daniele del Friuli (1985), his mother's birthplace, providing the specific locations for two of them. In another work titled The Once Mighty Elm (1976), housed at the Georgina Gallery, the tiny figure of a man walking on a road leading one knows not where passes by a dead tree. While there is life in the yellow and green in the lower section, the turbulent sky and leafless tree dominate the upper sphere in sharp contrast.

Chiarandini also did farm scenes and, although workers appear in some (for example, Onion Pickers from the mid-1970s, now in The Robert McLaughlin Gallery in Oshawa), these paintings are more frequently populated by a few cows viewed in the distance. In describing these works one journalist speaks of "the scenes of pastoral countryside in York Region ... now gone-the meadows and forests replaced with sprawling subdivisions." 32 But it is doubtful that Chiarandini's landscapes simply express pastoral tranquillity. Analyzed closely, they reveal elements of conflict that would seem to negate any possibility of idealism, as the upward movement of the yellow fields seems to anticipate a clash with the menacing blue

30 Murray, Canadian Art in the Twentieth Century, 61 and 62 uses this phrase and also "specific area of native soil," to describe the general tendency among Canadian artists to select a particular area to paint.

31 Two such scenes by Chiarandini, titled The Red Roof Barn and Autumn North of Toronto, were included in an exhibit My Backyard - Ontario by Gabi von Gans at the Steiner Gallery in Vienna in September 2009.

32 Slykhuis, "Priceless Collection," 18. 
forces from the sky above. His natural world certainly has elements of beauty - the fall colours and awesome winter scenes - but it is not a bower of bliss exempt from labour and harshness.

The presence of cows in many of his landscapes is particularly noteworthy. There are many dairy farms in southern Ontario that Chiarandini would have seen. But there also exists a well established artistic tradition of painting cows. In the nineteenth century various European artists depicted the animals either in connection with farmers toiling in the fields, as in the case of works by Giovanni Fattori (1825-1908), or in completely tranquil 'pastoral' settings. These mammals, of course, generally symbolize nourishment and motherhood, and connection to the land and nature. But the sombre mood created by the stormy skies above the cows in Chiarandini's works, for example the painting titled Gathering Storm (fig. 4), seems to make his an anti-pastoral depiction of them, not specifically because of the hard labour involved for the farm workers who, in fact, are often nowhere to be seen but as a general statement about life on earth.

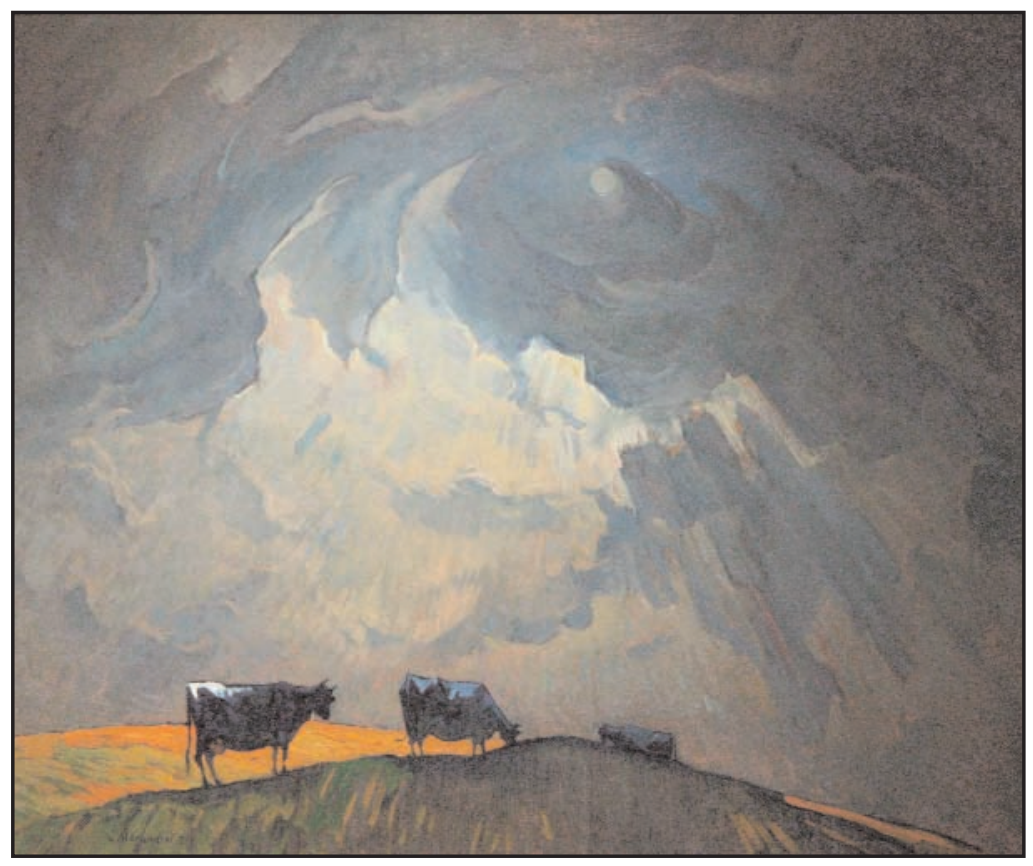

Figure 4. Gathering Storm, 1975. Oil on board, $101.6 \mathrm{~cm}$. x $121.9 \mathrm{~cm}$. Sutton West, Ontario, The Georgina Art Centre \& Gallery (Photo courtesy of the Estate of Albert Chiarandini)

Chiarandini's love of the modest scenery of small-town Ontario is evident in his painting of more urban locations too. A work from 1972 featuring the town of Streetsville presents a view of the backyard (1972) rather 
than the façade of a public building (perhaps a church). In his rendition of Saint James Anglican Cathedral (1956), a location emblematic of an important segment of establishment Toronto, visited by Queen Elizabeth II in 2010, for instance, the church is not the protagonist, as might have been expected. Rather, a plain building on the left, a red stoplight, and a hydro pole (typical of the Toronto streetscape) overshadow the cathedral, the 'ugly' hydro pole in the foreground appearing as tall as the church spire in the background, the wire from it extending over the façade of the cathedral to another pole. Several other similar treatments of this place of worship again feature the mundane accoutrements of Canadian streets partially covering the religious building.

Chiarandini preferred to paint the poor and more marginal sections of Toronto like the Bargain Store from 1977, in a manner comparable to that of Lawren Harris of the Group of Seven, famous for his house portraits of the slum Ward area of Toronto. ${ }^{33}$ Finding the national capital more attractive than Toronto, Chiarandini painted Ottawa's river, churches, and parliament buildings too, although the seat of government remains in the background, viewed from what appears to be the rear, with the fisherman's wharf occupying the foreground. Visiting Quebec City in the summer of 1970 before the October crisis, he recorded in his diary that he had painted nineteen scenes, including a house with a horse-drawn carriage in front of it. During his three trips to Italy in the 1970s and 1980s he visited Venice, Ravenna, Rome and Florence, but spent most of his time in Friuli and the Veneto, where he produced many rural scenes. One work executed during his first return to Italy in 1973 depicts his native city of Udine. He selects the heart of the city, Piazza della Libertà (Freedom Square), but quite characteristically, focuses on an obscure corner and not the main part of the monumental piazza. For Chiarandini, it would seem, it was the ordinary and unpretentious part of these monuments, government buildings, and churches that counted.

\section{Compositions}

Although there are also still lifes of flowers and fruit in Chiarandini's repertoire, including a depiction of apples on a tree from 1980 with swirls of movement in the sky glimpsed through the branches, what is of greatest interest is the number of large compositions that he produced. These enabled the artist to express his personal beliefs on moral, social, and political issues more openly. In his works in other genres, discussed above, his

33 Great Canadian Painting, 70. 
freely inspired portraits do feature the unfortunate and also freedom-fighters. While his country landscapes, anti-pastoral in tone, betray some turmoil, and his townscapes too focus on humble places, his cityscapes (those of Venice also ${ }^{34}$ ) often present important monumental structures from unusual angles. However, given that the 'narrative' works from the1960s and 1970s are, for the most part, considerably larger, and required, as the artist himself stressed, much time and patience-and, one may deduce, serious reflection too-they succeed in bringing together portraiture and land- or townscape in a complex manner. Inspired by current affairs in Canada, but also by some major events in Italy and from Friulian history, they present disturbing if not outright apocalyptic scenes that are even more provocative than his subtly stormy landscapes or his portraits of revolutionaries. By means of group scenes the artist presents even more explicitly a strong denunciation of war, hypocrisy, and materialism and brings the theme of human suffering explicitly to the fore. The 'warrior' artist is clearly visible in these works - in a literal sense too when, by means of certain personal cameo appearances and self-portrayals he is depicted fighting for justice and championing his principles.

There are three compositions that in the first place offer a marked commentary on Canadian politics. In two of them are inserted well-known Canadian prime ministers of the mid-twentieth century in unprecedented

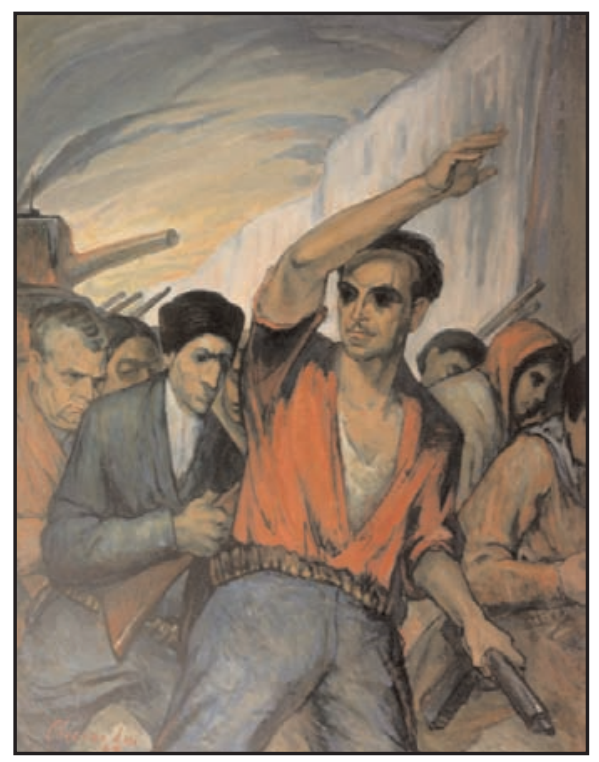
contexts. In the foreground of the composition titled The Masses (fig. 5) dating from the mid-1960s,

Figure 5.

The Masses, 1964.

Oil on board, $157.5 \mathrm{~cm} . \times 121.9$ $\mathrm{cm}$. Toronto, Chiarandini/Tadier Collection (Photo courtesy of the Estate of Albert Chiarandini)

34 Shaul Bassi of the University of Venice has identified the locations from which the Venetian scenes are viewed. 
depicting an armed crowd assaulting a fortress-like structure, the artist himself appears wearing a red shirt and carrying a machine gun. A group of seemingly radical followers are behind him. Among the rebels Chiarandini places none other than John Diefenbaker (1895-1979), the former Conservative Prime Minister by then leader of the opposition. Conservative ideology by definition champions the established order. Therefore, representing a head of government as attacking the fortressestablishment following the lead of a man of the brush is highly implausible. Yet the improbability ceases once one considers the fact that the painter is at the same time depicting an historical moment and an aspect of the human condition in keeping with what we have called his "symbolic realism."

The composition naturally caught the attention of several journalists, as the artist had intended it to, but when queried to give a reason for his portrayal of the Prairie lawyer, Chiarandini is supposed to have replied: "I want to capture the contradictory way in which human beings act, depending on the circumstances of the moment for war and peace. Diefenbaker was an individual with a strong character and unique expressions," 35 a not unsuitable characterization of the Conservative leader especially loyal to the Queen and a populist from the West.

The metahistorical message contained in the composition is further suggested by the citation embedded in the figuration. The painting clearly recalled is Delacroix's La liberté guidant le peuple of 1830. In that canvas the painter is depicted as carrying a gun rather than a brush, thereby claiming a leadership role in the fight for freedom. In The Masses Chiarandini also is armed with a rifle leading a fight for the benefit of the people, the blind masses. His red shirt is indicative of his strong passion for the cause and his occupation of the centre of attention, with even a former prime minister as a follower, is proof of the great value that Chiarandini attached to the role of the artist as a conveyor of a more complete message with respect to reality and the human condition.

Equally arresting is his large painting of 1971 titled Man's Instinct (fig. 6). One of his studies on modern materialism, it presents a series of figures striving to reach the top of the greasy pole in order to win the prize, in a predominantly blue, skyward view that may recall Tiepolo's ceiling frescoes in Udine, as has been suggested. ${ }^{36}$ Among the figures avidly grasping with

35 Hanlon, 10. A photograph of the painting appears in The (Financial) Telegram (8 April 1967): 16.

36 The observation is by Anna Pia De Luca of the University of Udine. 


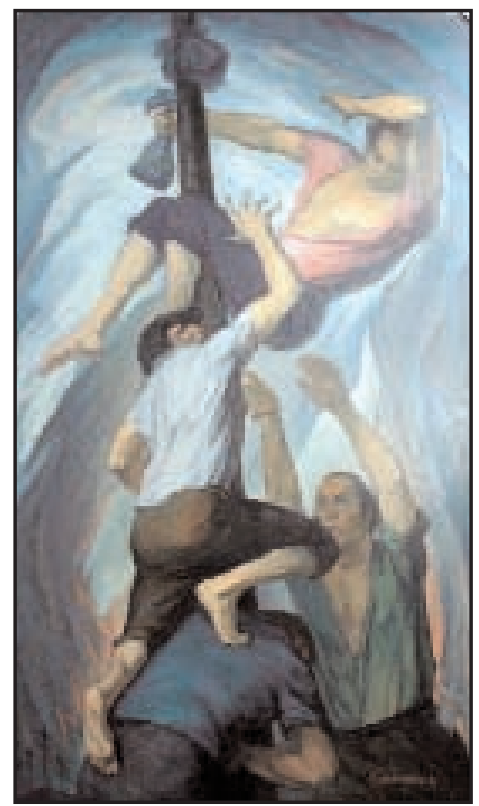

Figure 6.

Man's Instinct, 1971.

Oil on board, $213.4 \mathrm{~cm} . \times 121.9 \mathrm{~cm}$. Sutton West, Ontario, The Georgina Art Centre \& Gallery (Photo courtesy of the Estate of Albert Chiarandini)

their hands and clambering over their rivals, we find once again the artist himself and, most visible in the group, the immediately recognizable Liberal prime minister of Canada at the time, Pierre Elliott Trudeau (19192000, prime minister 1968-79 and 1980-84). Significantly, however, in this hierarchy it is the artist who reaches the summit while Trudeau remains at the bottom right of the scene with a newspaper in his pocket that bears the headline "Fight Inflation." The strong lines of the background and swirling brush strokes, characteristically suggesting turbulent clouds, as in many of Chiarandini's works, indicate storminess. At the time of this painting serious economic problems faced the nation and Trudeau's popularity was waning. Later in 1975 the prime minister was, in fact, to reverse his campaign promises and introduce wage and price controls to combat inflation. But before Chiarandini executed the painting Trudeau had already aroused much controversy by invoking the War Measures Act to quell the Quebec crisis of October 1970 when the provincial minister Pierre Laporte was kidnapped and murdered. Although a supporter of the New Democratic Party, Chiarandini had helped a fellow Italian Canadian, the Liberal candidate Charles (Carletto) Caccia, in the 1968 electoral campaign. His painting may express some disappointment with the Trudeau government. Interestingly, in order to make this political statement, Chiarandini adopts as his objective correlative the greasy pole game that represents the dreams of the poor for a sudden windfall. A once popular 
country festivity, the artist may very well have witnessed it in Italy in his youth or later in Canada at the early Famee Furlane of Toronto picnics.

Chiarandini depicting himself as winning the prize, although after great effort, as indicated by his disheveled clothing, makes a similar point as The Masses in respect of art. The artist emerges as the victor in the struggle for the windfall reward - not in terms of wealth, as attested by the tattered clothing - but as an exponent of life's goals which are to be found above materialism and politics but that arise from the struggle in the material sphere.

Another of Chiarandini's compositions from 1971 relates directly to Quebec. It chronicles specific movements that were part of recent Canadian and Quebec history (fig. 7). In it a band of demonstrators is led

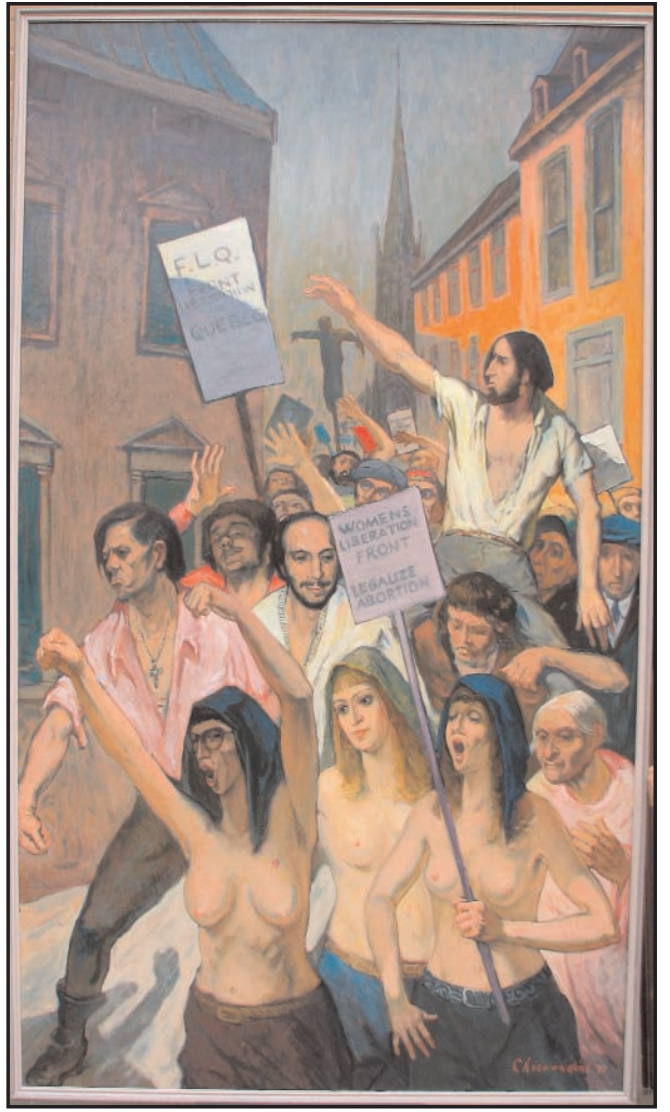

Figure 7.

FLQ/Liberation Movement, 1971. Oil on board, $214 \mathrm{~cm} \mathrm{x}$ $122 \mathrm{~cm}$. Toronto, Chiarandini/Tadier Collection (Photo courtesy of the Estate of Albert Chiarandini)

by a group of women, three of whom are young and bare-breasted and one elderly and fully clothed. One member of the bra-burning trio carries a banner reading "WOMENS LIBERATION FRONT / LEGALIZE ABORTION," and two are openmouthed, clearly chanting slogans as they 
protest. The men behind them, hoisting a banner promoting instead the "F.L.Q. FRONT LIBERATION DU QUEBEC," bear features identifying them as the leaders of the movement responsible for the kidnapping of James Cross in October of 1970: Marc Carbonneau in the middle at the front and perhaps Yves Langlois on high at the back. Strangely, the face of Cross appears on the man to the left wearing the pink shirt and a pendant in the shape of a cross, as Joan and Pat Tadier recently discovered on the basis of newspaper clippings and photos found among the artist's papers. The diplomat Cross ironically has been made to join the movement, it would appear. Representing the three younger women as bare breasted and well endowed Chiarandini stresses their vital urges and nurturing role and hence their right to have a voice in their life choices. The vocal but not violent protest of the men would attest to the admissibility of their cause. In any event, the composition acknowledges the rise of new forces, commensurate with new global ideologies, in Canadian life.

An event in the history of Friuli-well-known in the popular memory of all Friulians-provides the subject matter for another large composition of a few years later in 1979 (now in the Georgina Gallery). It deals with Attila and the Huns burning Aquileia in the fifth century. The fiercelooking soldiers dominate the painting and dwarf the tiny built-up area of civilization located in the bottom left-hand corner, the contrast in size reinforcing symbolically the idea of the force of the conquering hoards. The horns on the Huns' helmets, though they may reflect actual military dress, must represent evil, as does the black horse on which Attila rides.

Another large work from 1972, painted in various shades of blue and areas of white and titled Man's Iniquity (fig. 8), also serves to denounce the horrors of modern warfare. The huge tanks and black mass of soldiers in the background represent anonymous brute force attacking a citadel that resembles the traditional imaging of the Tower of Babel. The foreground is occupied by the grief-stricken victims, many of whom are women wearing kerchiefs and shawls draped over their heads, with one of them sitting uncomfortably on the ground cradling a very small child in her arms, together with young children. The pride of place accorded to the victims individualizes and humanizes them in their suffering and grief, while it underlines the horrors of war. These interpretative paintings by Chiarandini differ from the graphic and quasi-photographic works by many of the Canadian war artists of the 1940s, some of whom, however, Lawren P. Harris, for example, were, like Chiarandini, less conservative, portraying the scenes in a more surreal manner. ${ }^{37}$ In Chiarandini's war

37 Murray, 80-83. 


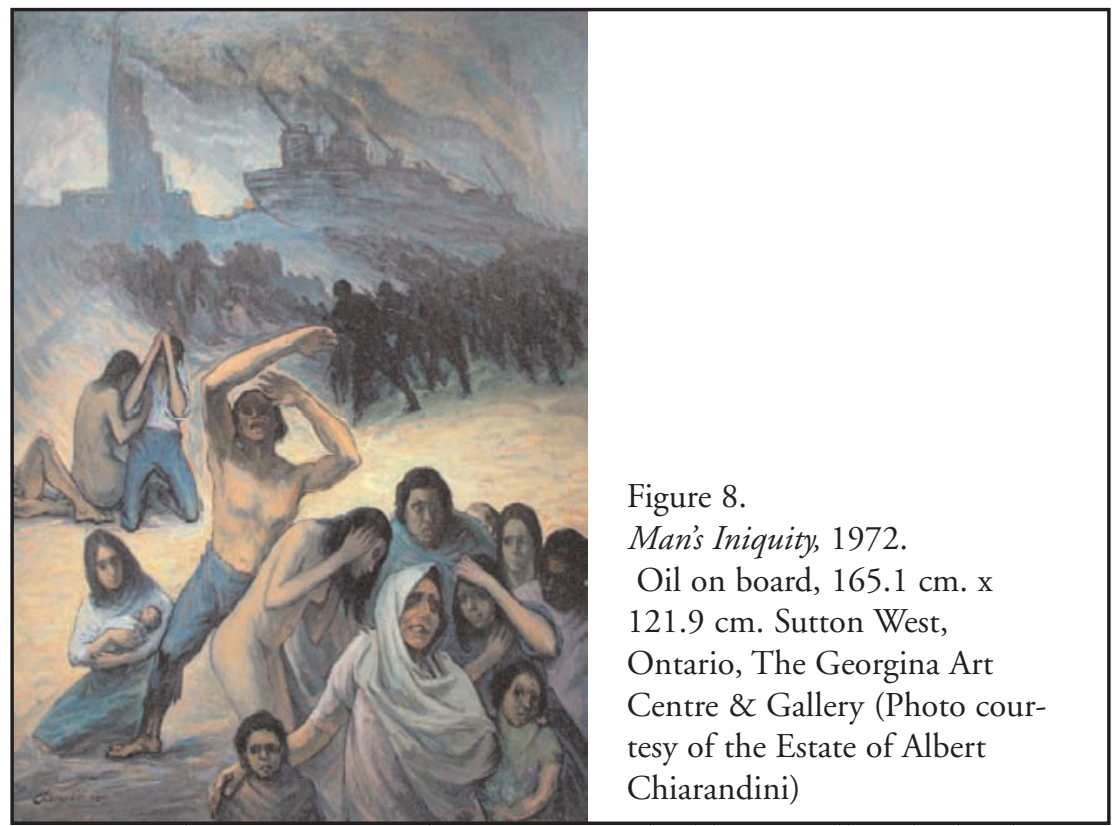

paintings, the occasions are less circum scribed historically. The landscapes in them are non specific and yet, appearing more European than North American, they may reflect the fact that the artist associated such military events and human suffering with the old world where he had had direct war experiences as a child.

In another work titled Under the Sign of the Cross (1976 fig. 9) is

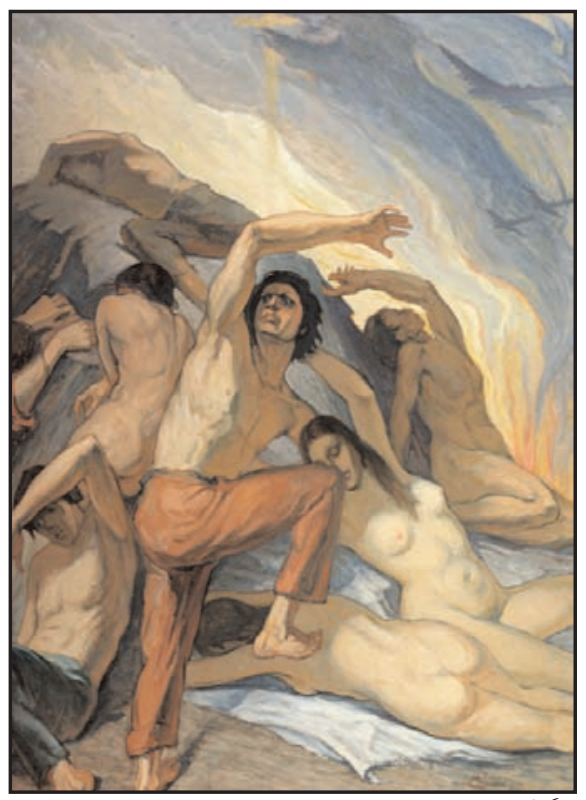
depicted a purgatory-like scene emblematic of the earthly desire

Figure 9.

Under the Sign of the Cross. 1976.

Oil on board, $172.7 \mathrm{~cm} . \times 121.9$ $\mathrm{cm}$. Toronto, Chiarandini/Tadier Collection (Photo courtesy of the Estate of Albert Chiarandini) 
to climb to the top in life. The ascent is strictly for material success with each person stepping on his fellow human being to gain the edge. There are women too, figured naked and very attractive, literally embodying the sensual pleasures that presumably would attend the successful climbers. The colours are bright with blue, orange and off-white predominating. But, when all the figurative elements are considered, the truth being conveyed is quite the opposite. The climber who has reached the top is lying face down on the ground as either totally exhausted or dead. The beautiful women are seemingly lifeless. The man at the centre of the painting has a very troubled look. Other very significant details: three figures, including the central one, have an arm in a protective gesture around their foreheads; an illuminated cross is clearly visible in the sky; birdlike shapes are approaching from the right toward the 'earthly paradise,' a closer look revealing them to be planes, plausibly bombers; the sunlit clouds on the right have all the semblance of flames. The idea that the pursuit of material success is a vain labour is further underlined by the embedded figurative elements utilized by Chiarandini. Behind the cross of Christ and the defensive arm posture is Michelangelo's portrayal of the triumphal Christ in the Last Judgment from whom there is no escape. But of course, the unhappiness that attaches to the strictly earthly ideal of material success, as pointed out, occurs in Chiarandini's work without the religious connection.

In another composition from 1973 featuring the vices of man, a large crucified figure (not just a cross) dominates much more visibly at the top of the rocky terrain. But, confined to the background, it contrasts with the figures that in the foreground move outward toward the viewer, namely, two ravens, a violent man with a whip, a couple representing licentiousness, a man bent over worshipping gold coins, and finally a dark, Judas-like figure who flees with a bag (presumably of gold), the pig behind him representing the greed that spurs him on. In spite of the presence of the crucified man, resembling Christ, the figures that dominate are those symbolizing the vices and not the virtues of humankind.

A smaller and earlier composition from 1960 depicts a religious procession made up of a number of both humble villagers and distinguished personages. At the head of the line cardinals proceed wearing their mitres, and church banners and large crosses are carried on high. Yet the leaders of the procession, seen in the distance, are minuscule. They are reminiscent of the churches often relegated by the artist to the background of city- and townscapes as well as the FLQ painting discussed above, their small size indicating perhaps a diminished role and limited power for the church in 
modern society and in Chiarandini's secular worldview. The large figure in the foreground, representing by contrast the tail end of the procession, is a one-legged man. He stands out against the rocky terrain because of his reddish brown trousers similar in colour to the robe worn by Savonarola in Chiarandini's interpretative portraits, possibly symbolizing sacrifice. A neglected war veteran, one might surmise, his muscular but wounded body stands on the boulders, his head framed by the dark turbulent sky above. The organization of the scene may suggest the view that the official Church is rich in raiment but minuscule in size, designed to illustrate its almost negligible function when it comes to helping the poor.

In addition to war episodes, natural disasters that cause human suffering also captured Chiarandini's imagination. For the painting of 1981, which he titled God Abandoned Us for Seven Days (fig. 10), the artist was

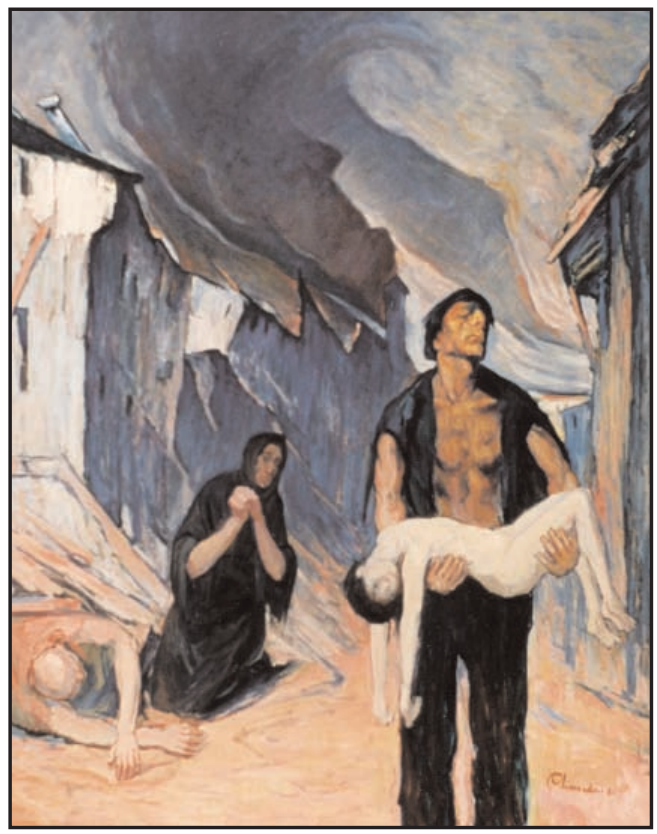

Figure 10.

God Abandoned Us for Seven Days. 1981.

Oil on board, $147.3 \mathrm{~cm} . \mathrm{x}$ $121.9 \mathrm{~cm}$. Toronto, Chiarandini/Tadier Collection (Photo courtesy of the Estate of Albert Chiarandini)

inspired by the 1980 earthquake in isolated villages of Campania, Italy, where help was slow to arrive. It is likely that the similar devastation that had hit his native Friuli four years earlier was also a factor. Amid collapsing buildings and under a dark sky representing the force of nature, an old lady prays, while the stark, white, dead body of a child is heroically carried out of the rubble by a strong tanned man with a grim look of resignation on his face and eyes closed. Here the colour white seems to represent a ghostly lack of life, rather than the type of luminosity that in earlier art (of 
the Renaissance, for example) could signify an ethereal or even spiritual presence. This painting illustrates the view that Chiarandini could see beauty and awesomeness in nature but that he saw in it as well a self-operating system that could be calamitously destructive, against which human beings, who must live in it, rather than fighting one another for personal self-interest should develop their own system of values to combat it.

Consistent with this worldview is also the 1979 painting by Chiarandini titled Caprice: Dante's Inferno, an otherworldly landscape inspired not by a specific place but by a famous text, central to Italian culture, and populated with nude figures. In view of the title, one might expect to see an illustration of a single canto in the Divine Comedy. Instead, we are again presented with a generic rendering of human bodies that struggle on rocky terrains. It is significant that Chiarandini selected the first canticle, and not the Purgatorio or Paradiso. His landscapes discussed above may show fertile land in the lower field, although storm clouds gather above, but where humans are involved, as in these compositions, earth (or earthly existence) is inevitably harsh and conflictual.

\section{The gaze of the 'warrior' artist in the self-portraits}

In addition to portraying himself as the leader of revolutionaries and as the jackpot winner on high in two of the compositions analyzed above, Chiarandini presented himself as a 'warrior' of sorts in some of the numerous self-portraits which he painted throughout his career. A comparison between a few of these from different periods illustrates his development as an artist in pursuit of his distinctive voice. ${ }^{38}$ In a 1938 self-portrait, which is likely a mirror image, since a bit of the frame is seen in the painting and the right-handed artist is holding a brush in what appears to be his left hand, the artist wears his official artist's smock, yellow in colour, with a contrasting black ascot, and adopts a somewhat stiff pose, as he attempts perhaps to establish his identity as an artist during the first years in Canada. The palette in one hand, he holds the brush delicately with index finger extended. Not a speck of paint is to be seen on his clothes or on his body. The image is conventionally thoughtful and elegant, as befitted a serious portrait painter of the middle classes. In 1956 he appears in a traditional three-quarters pose in gold and brown hues with light reflecting on his forehead. Although in this bust no hands or painters' tools are visible, his eyes penetrate those of the viewer, as we realize he is studying us

38 Important commentary on his self-portraits is provided by Christie Jones in the brochure cited above. 
closely. Some of the subsequent self-depictions stand out for the array of poses adopted. In 1962 he presents himself frontally with very large eyes, wearing an open jacket, his right hand opening, ready to receive the images of the world. A version of this is found, along with the Meyer Ellison portrait mentioned above, in the National Archives of Canada in Ottawa. Chiarandini always portrayed himself with large eyes, made even larger in later years by his oversized eyeglasses, highlighting the artist's vision and perceptiveness. 39

Two self-portraits that perhaps provide a figurative statement of his mature artistic credo were executed in 1978 and 1982. In the relatively small earlier work, now at the Georgina Gallery, there is again the stern look, the large glasses and eyes to reconfirm his unrelenting gaze, but a new feature is added: his right hand closed in a fist with the index finger pointing straight upwards (fig. 11). The figuration is stark with his portrait (head and shoulders, white shirt open at the collar, with the right hand showing) set against a reddish background. It contains no additional details. This must be taken to mean that he is quite clear on what his art

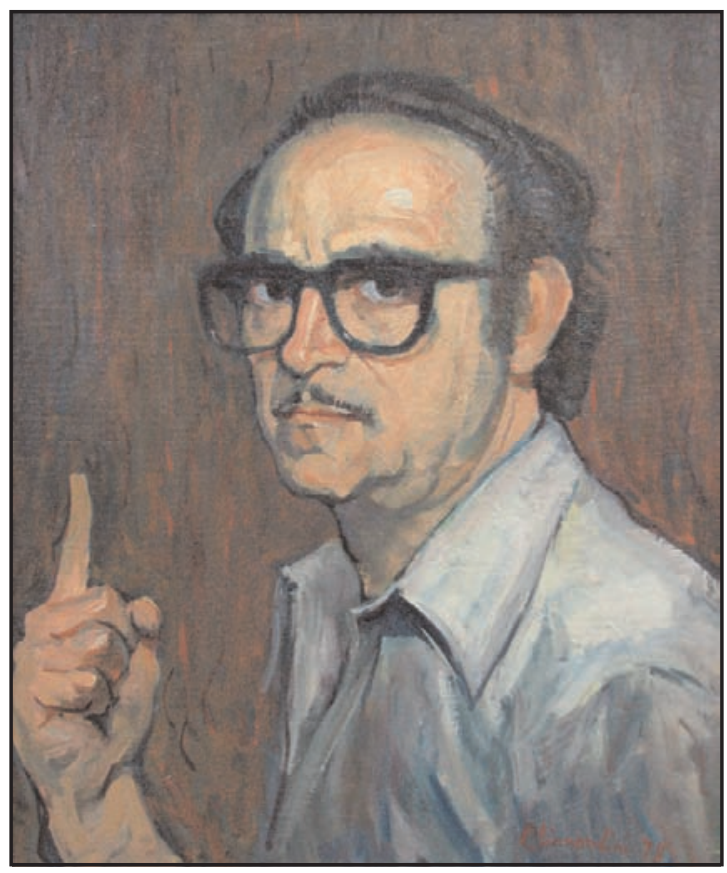

Figure 11.

Self-portrait with Raised

Finger. 1978.

Oil on board, $50.8 \mathrm{~cm} . \mathrm{x}$

$35.6 \mathrm{~cm}$. Sutton West,

Ontario, The Georgina

Art Centre \& Gallery

(Photo courtesy of the

Estate of Albert

Chiarandini)

39 Thanks go to Anna Pia De Luca and to her students for their comments on the search for identity and the echoes of Salvador Dalí evident in Chiarandini's selfportraits. 
will be: forceful, uncompromising, insightful or at least the product of a 'large vision'. The upward-pointing finger, clearly recalling two famous Renaissance masterpieces, Raphael's School of Athens where Plato's similar gesture points to the immaterial world of ideas and Leonardo's St. John the Baptist pointing to a spiritual heaven, indicates implicitly that Chiarandini's unvarnished rendition of reality will not be devoid of the values of the spirit, neither in portrayal nor in inspiration. In other words, his art will not simply be characterized by a flat photographic realism.

In the huge 1982 self-portrait the basic message about his art is restated with further significant additions. It is an almost life-size study of himself titled Eye of an Elder (fig. 12) in the Georgina Gallery collection; in it

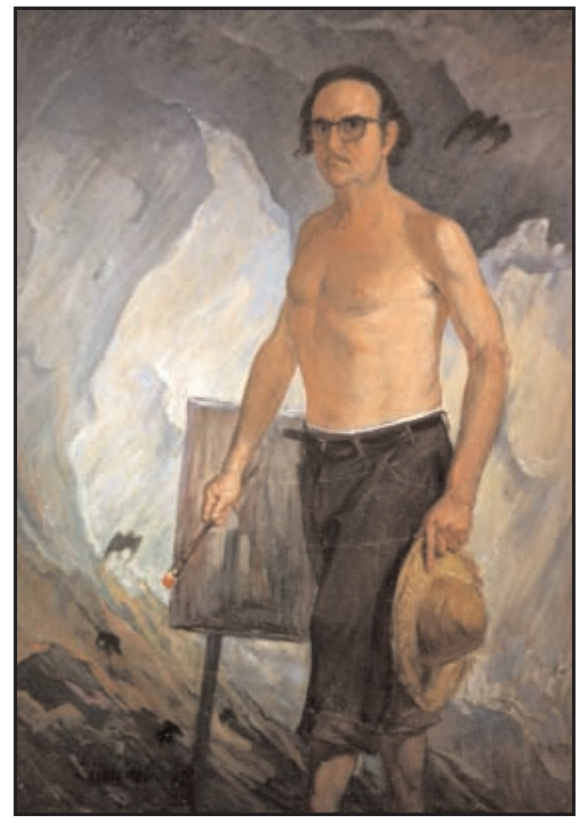

Figure 12.

Self-portrait with Straw Hat. 1982.

Oil on board, $157.5 \mathrm{~cm} . \times 121.9$

$\mathrm{cm}$. Sutton West, Ontario, The Georgina Art Centre \& Gallery (Photo courtesy of the Estate of Albert Chiarandini)

he displays a completely nude torso, as he turns away from the canvas, a worn-out, wide-brimmed straw hat (that apparently he liked to wear) in his left hand. Again he looks out sternly toward the viewer but in this selfportrait a turbulent sky looms behind him and he holds the paintbrush in his fist quite tellingly in an almost menacing manner, to suggest the commitment and passion that he brought to his art.

The composition seems to make another point that links it to the 1978 self-portrait. And it is this: although the painter is in a natural setting, in a working outfit, the best to capture the scene with his eyes and transfer it to canvas (painting en plein air was a central principle of his art), the truth that he must portray encompasses more than the visual image. 
On closer inspection the painting recalls in visual terms Plato's so-called 'Myth of the Cave'. That allegory purported that the phenomenal world offers only shadows; the real world is that of the true forms or ideas which can only be reached not just by the eyes but by the intellect. The place in which Chiarandini works is the open air-a physical place-but the configuration of the colours and light makes it look like a cave. This is not to say that Chiarandini is Platonic. On the contrary, he does not portray himself as the serene and venerable old man in Raphael's work who receives his wisdom from positing and contemplating a transcendental sphere as its true locus. Rather, as the all too human image of himself in the 1978 and 1982 self-portraits, he must struggle and labour in the strictly earthly sphere to attain the existential truth. What Chiarandini's mediated Platonic gesture seems to signify is that the values and truths the artist must express are empirically determined but transcend the immediately materialistic concerns of everyday life. It was art and creativity that, conceived in these encompassing terms, gave direction to his own life.

Another related work from 1989 is equally telling. In it he places an artist (himself perhaps?) in a unique context and unusual pose, probably teaching an art class, although no students are visible. On the left side of the painting, we see the art teacher wearing his white smock, but quite comfortably now, as he stands before a blank canvas, on which his shadow is cast, perhaps about to begin the lesson. On the right side of the painting, dominated by a white translucent curtain, a model poses in the nude on a raised platform in the foreground. Three paintings already completed are on display on the wall and on the floor probably as samples being shown to the students. Of these the most prominent, located on the extreme right, features the street person Meyer, whom he had begun to paint fifteen years earlier, in front of a building, but the proportions have been altered, Meyer having been much enlarged and the structure behind him reduced in size. Quite unusually, though, in this work the artist has his back to the viewer, still keeping his face hidden as he begins to turn toward the class. In this manner he highlights not his own presence but the subjects of his painting and these are quite remarkable: the shapely model juxtaposed to the paunchy figure of Meyer. In this light-filled meta-artistic painting about painting, two very different aspects of the world examined by the artist converge, beauty on the one hand and social concern on the other. The artist-teacher is content to stand to the side, no longer needing to show his face, his art and his art lessons now the vehicles for conveying truths about the contrasting facets of life which he has spent his own life studying and which he wishes to champion. 


\section{Conclusion}

It is true that Chiarandini's paintings chronicle persons, locales, and events not captured by other artists before him in Canada, and it is equally undeniable that his paintings depict delightful scenes of Canada and Italy that are executed with full mastery of the art of painting. Yet his achievements go far beyond the "historical documentation and beauty of both Italy and Canada" 40 that have been recognized in his works. With his weapon-like paintbrush Chiarandini has indeed penetrated the heart of human existence, revealing the inner and outer turmoil of life as he knew it. For this he deserves to be hailed as a great international artist in whom Italian (not to mention Friulian) and Canadian traditions converge to produce paintings that, while based on concrete reality, are rich in symbolism and suggestive of universal meanings. And the message that he stresses and that constitutes the common thread throughout his production is the need for justice for the poor, the victimized, and the marginalized of society—goals that, in his view, the creative 'warrior' artist like himself could and should tackle.

\section{UNIVERSITY OF TORONTO}

\section{Works CiTED}

Artists in Canada. A Union List of Artists' Files (National Gallery of Canada, Library and Archives, Occasional Paper No. 3). Ottawa: National Gallery of Canada, 1999.

Chiarandini, Albert. The Masses, photograph with the caption Diefenbaker... the Revolutionary, The (Financial) Telegram (8 April 1967): 16.

Chiarandini, Albert. "Diaries," and album of documents including letters, and also his mother Giovanna's diary now published in Olga Zorzi Pugliese, "Le memorie di una friulana in Canada: il Diario di Giovanna Gallino Chiarandini" with "Una postilla sulla lingua" by Rienzo Pellegrini, Metodi \& ricerche. Rivista di studi regionali, n.s. 28.2 (luglio-dicembre 2009): 105-145. Estate of Albert Chiarandini.

Chiarandini, Albert. Information Form, The National Gallery of Canada, 1965. Dixon, Guy. "Report on the 2011 Venice Biennale," The Globe and Mail, 3 August 2010 (online).

Dryden, Murray. With God Nothing is Impossible. A Canadian Life. Markham, ON: Fitzhenry \& Whiteside, 1985.

Glionna, Jaclyn. "Chiarandini," The Group of Seven Project 1920 2005. Ed. Dennis Reid et al. Toronto: Ontario Association of Art Galleries (OAAG), 2010.

40 Brochure from the Italy to Canada exhibit at the Georgina Arts Centre \& Gallery. 
Great Canadian Painting: A Century of Art. The Canadian Centennial Library. [Toronto]: McClelland and Stewart, 1966.

Hanlon, Michael. The Globe and Mail (1 June 1964): 10.

Jones, Christie. "Portraits 2007." Portraits Exhibition Guide. The Georgina Art Centre \& Gallery, August-September 2007.

Katz, Sidney. "Derelicts Need Love, Artist Says," Toronto Daily Star (12 March 1966): 62.

Martel, Marcel. “'They Smell Bad, Have Diseases and are Lazy': RCMP Officers' Reporting on Hippies in the Late Sixties." The Canadian Historical Review 90.2 (June 2009): 215-245. Reprod. The Sixties in Canada: A Turbulent and Creative Decade. Ed. M. Athena Palaeologu. Montreal: Black Rose Books, 2009, 165-192.

Mc Mann, Evelyn de R. Biographical Index of Artists in Canada. Toronto, Buffalo, London: University of Toronto Press, 2003.

Murray, Joan. Canadian Art in the Twentieth Century. Toronto, Oxford: Dundurn Press, 1999.

Pouliot, Lorenzo. Cahier généalogique Pouliot. Québec: Bibliothèque Nationale du Québec, 1978-79.

Pugliese, Olga Zorzi. "Personalities, Landscapes, and Politics of Central Canada in the Paintings of Albert Chiarandini (Udine 1915 - Toronto 2007)." Investigating Canadian Identities: 10th Anniversary Contributions. Ed. Anna Pia De Luca. Centre for Canadian Culture Studies Series. Udine: Forum Editrice, 2010, 143-166 (including 8 illustrations, 159-166).

Richmond, John. "City Faces: The Portrait Artists Sell Immortality in Oil, Bronze ... ," Toronto Calendar Magazine, 6th year, No. 12 (15 November - 5 December 1974): 45.

Rotunno, Caterina. “Inspired by Canada': An Intercultural Celebration. Columbus Centre and McMichael Galleries Pay Homage to Group of Seven," Tandem/Corriere canadese (10 April 2011): 5.

Slykhuis, John. "Priceless Collection Puts Gallery on Map," Georgina Advocate (16 December 2004): 1 and 18.

Tadier, Joan Chiarandini. E-mail communication to Pugliese, August 2005 and June 2008.

The Ontario College of Art Prospectus 1936-1937.

The Ontario College of Art Prospectus for Session 1934-1935.

The Ontario College of Art Quarterly, 1.2 (1966).

Unsigned. "Chiarandini Discovered: Georgina Arts Centre \& Gallery Lands Priceless Collection," Art Galleries of York Region [McMichael, Varley, Lachman, Georgina], (Winter Edition 2005/2006): 4.

Unsigned. Italy to Canada. Exhibit Brochure, Georgina Arts Centre \& Gallery, January 2006.

Unsigned. Report on the 2011 Venice Biennale, Toronto Star (3 August 2010) online.

Unsigned. "Columbus Centre and the McMichael Unite for One Night: Two 
Galleries Present Unique Intercultural Exhibition by Artists of Italian Heritage," Tandem/Corriere canadese (27 March 2011): 5.

Vid[oni], Fl[avio]. "Lartista novantenne che ora vive al Friuli Center. Il sogno di

Chiarandini. Un'opera al GAMUD,” Il gazzettino di Udine (26 ottobre 2005): 14.

Vidoni, Flavio. "Il pittore degli hippy," Il Friuli. Cultura. Settimanale (18 febbraio 2011): 25 .

Whyte, Murray "Steven Shearer Gets in Art World's Face: Off to Venice with a Certain Rudeness," Toronto Star (31 May 2011): E1, E7.

Who Was Who in American Art 1564-1975. 400 Years of Artists in America. Ed.

Peter Hastings Falk, Vol. 1. Madison: Sound View Press, 1999. 634.

www.albertchiarandini.com

www.ontariosocietyofartists.org

www.studio737.com/Albert Chiarandini 